\title{
Characterization of a Bacillus thuringiensis strain collection isolated from diverse Costa Rican natural ecosystems
}

\author{
Glen Arrieta ${ }^{1}$ \& Ana M. Espinoza ${ }^{1,2}$ \\ 1 Centro de Investigación en Biología Celular y Molecular (CIBCM), Universidad de Costa Rica, Sabanilla de Montes \\ de Oca, San José, Costa Rica; garrieta@costarricense.cr \\ 2 Escuela de Agronomía, Facultad de Ciencias Agroalimentarias, Universidad de Costa Rica, San José, Costa Rica; \\ amespino@racsa.co.cr
}

Received 18-IV-2005. Corrected 21-VII-2005. Accepted 20-IX-2005.

\begin{abstract}
Costa Rican natural ecosystems are among the most diverse in the world. For this reason, we isolated strains of the entomopathogenic bacteria Bacillus thuringiensis $(B t)$ to determine their diversity, distribution and abundance. A total of $146 \mathrm{Bt}$ strains were obtained from environmental samples collected from diverse natural ecosystems and life zones of Costa Rica. We recovered $B t$ strains from $71 \%, 63 \%, 61 \%$ and $54 \%$ of soil samples, fresh leaves, other substrates and leaf litter respectively. Bt was isolated in $65 \%$ of the samples collected in the humid tropical forest in national parks (Braulio Carrillo, Gandoca Manzanillo, Sierpe, Hitoy Cerere, and Cahuita), and in $59 \%$ of the samples collected in the dry tropical forest (Parque Nacional Marino las Baulas, Palo Verde and Santa Rosa). In the very humid tropical forest (Tortuguero) $B t$ was isolated in $75 \%$ of the samples and in the very humid tropical forest transition perhumid (Carara) it was found in $69 \%$ of the samples. The strains exhibit a diverse number, size and morphology of parasporal inclusion bodies: irregular (47\%), oval (20\%), bipyramidal (3\%), bipyramidal and cubic (1\%), bipyramidal, oval and irregular (5\%) and bipyramidal, oval and cubic crystals (2\%). Strains isolated from Braulio Carrillo, Tortuguero and Cahuita, presented predominantly irregular crystals. On the other hand, more than $60 \%$ of the isolates from Térraba-Sierpe and Hitoy-Cerere had medium oval crystals. Strains from Gandoca-Manzanillo, Palo Verde and Carara presented mainly combinations of oval and irregular crystals. Nevertheless, the greatest diversity in crystal morphology was observed in those from Santa Rosa, Llanos del Río Medio Queso and Parque Marino las Baulas. Protein analyses of the crystalspore preparations showed $\delta$-endotoxin with diverse electrophoretic patterns, with molecular weights in the range of 20 to $160 \mathrm{kDa}$. Fifty six percent of the strains amplified with the cry 2 primer, 54\% with vip3, 20\% with cry 1, 9\% with cry3-cry 7 and $8 \%$ with cry 8 . The cry 11 and cyt genes were found in $8 \%$ and $7 \%$ of the strains, respectively. When analyzed with specific primers for the cry 1 subfamily, 13 different genetic profiles were obtained. In addition, twenty-four strains did not amplify with any of the primers used, suggesting they contain novel cry genes. The diversity of $B t$ genes found in this collection indicates it could have great potential for the control of different species of insect pests. The toxicological characterization of the strains by bioassays against important insect pests will provide useful information about their potential use for the formulation of biological insecticides and their respective cry and vip genes for the transformation of crops to confer resistance to insects. Rev. Biol. Trop. 54(1): 13-27. Epub 2006 Mar 31.
\end{abstract}

Key words: Bacillus thuringiensis, crystals, cry, vip genes, $\delta$-endotoxins, national parks, Costa Rica.

Costa Rica is one of the 20 richest countries in terms of biodiversity, harboring $4 \%$ of the total biodiversity of the world (Obando 2002). The geographic location of the country in the neotropics, its geology, two closely separated coasts, a complex mountain range system and diverse microclimates and ecosystems are some of the determining factors for the biological diversity of the country. The neotropics provide a rich source for the discovery of new species and strains of microorganisms. Therefore prospecting for gene 
diversity is envisage as a promising investigative area of the 21 st century, giving Costa Rica a unique opportunity to lead the process in the region. The genetic resources obtained from microorganisms play an important role in the production of new enzymes, antibiotics and bioinsecticides by the biotechnological industry (Bull et al. 1992, Samsonov et al. 1997).

It has been estimated that 67000 species of plagues affect agriculture in the world, and approximately 9000 species are insect pests (Ross and Lembi 1985). As a result, sustainable control of insects in agriculture is crucial since, for 2001, it was estimated that chemical worldwide control of insects cost 7500 million dollars (James 2002). In addition, the use of synthetic insecticides is not recommended because of the undesirable effects on human health, ecological problems caused by their slow degradation and the lack of specificity in their insecticidal action. This situation has stimulated the search of new alternatives of insect control based on the entomopathogenic bacteria Bacillus thuringiensis (Bt).

$B t$ is a Gram positive bacteria of the Bacillaceae family that has been used as a bioinsecticide for the biological control of plagues of economic importance in agriculture over the last decades (Aronson et al. 1986). This bacteria synthesizes crystalline insecticidal proteins or $\delta$-endotoxins. These $\delta$-endotoxins form parasporal inclusion bodies, which are very toxic and highly specific to the target insect but are innocuous to animals and humans (Betz et al. 2000). Bt-based bioinsecticides have been formulated against lepidopteran and coleopteran larva of plant pests as well as against mosquitoes and black flies, which are vectors for a variety of human diseases (Bravo et al. 1998).

Most $B t$ strains produce $\delta$-endotoxins encoded in the cry and cyt genes contained in megaplasmids of more than $30 \mathrm{Mda}$. These toxins were originally classified by Hofte and Whiteley (1989) into four classes (Cry1, Cry2, Cry3, and Cry4), according to their amino acid sequence similarity and their insecticidal toxicity. More recently, Crickmore et al. (1998) established a new classification system based solely on the amino acid homology, resulting in 34 classes of Cry proteins. In addition, Estruch et al. (1996) discovered that some Bt strains also synthesize Vip insecticidal proteins during the vegetative growth phase. Both Vip and Cry proteins act in the midgut epithelium causing intestinal paralysis, cellular lysis and finally insect death.

The identification of Bt cry and cyt genes by PCR has proven to be a very useful method for strain characterization, offering several advantages in terms of rapidity and reproducibility (Ben-Dov et al. 1997, Porcar and JuárezPérez 2003). A single $B t$ strain can harbor up to eight different cry genes (Martínez 2002). In general, the type of cry and cyt genes present in a strain correlates to some extent with its insecticidal activity (Porcar and Juárez-Pérez 2003). Thus, the identification of the gene profile in a $B t$ collection can be a useful tool to predict its potential insecticidal activity.

Since Costa Rican insects diversity is estimated to be 360000 species (Obando 2002), and because a co-evolution of $B t$ strains and their susceptible insect hosts has been proposed (Apoyolo et al. 1995), prospecting for $B t$ strains in diverse natural ecosystems could result in the identification of Cry proteins with new specificities. The objective of this research was to isolate and characterize a collection of $B t$ strains from natural ecosystems, representing the diverse life zones of Costa Rica. The results obtained offered information about the prevalence of $B t$ in the country and the distribution, abundance and diversity of $B t$ strains. Those strains could be used in the near future in the formulation of insecticides for the biological control of insects of economic importance for the country. In addition, their cry genes could be used for the genetic transformation of plants.

\section{MATERIALS AND METHODS}

Sample collection: Two hundred and sixty five environmental samples (soil, leaf litter, fresh leaves and other substrates) were 
collected from protected areas that include the diverse ecosystems and life zones of Costa Rica (Fig. 1). One hundred samples were collected from the humid tropical forest (Braulio Carrillo, Gandoca Manzanillo, Sierpe, Hitoy Cerere, and Cahuita), 80 from the dry tropical forest (National Park Marino las Baulas, Palo Verde, Santa Rosa), 24 of the very humid tropical forest (Tortuguero) and, finally, 61 samples from the humid tropical forest transition perhumid (Carara). The samples were dried at $50^{\circ} \mathrm{C}$ for 24 hours and stored at room temperature.

Isolation of Bt: Bacteria were isolated using the protocol described by Travers et al. (1987) using T3 as selective enrichment medium. Sporulated cultures showing the typical $B t$ morphology were preserved both on filter paper at room temperature and in $50 \%$ glycerol at $-70^{\circ} \mathrm{C}$.

Light microscopy: Cultures of approximately five days were analyzed by light microscopy (Nikon E-200 Eclipse) by staining with
Coomassie blue $(0,25 \%(\mathrm{w} / \mathrm{v})$ in $60 \%$ ethanol $(\mathrm{v} / \mathrm{v})$ and $7 \%$ of acetic acid $(\mathrm{v} / \mathrm{v})$, with the purpose of determining crystal morphology.

Polyacrylamide gel electrophoresis: Crystal-spore preparations were analyzed for the presence of the $\delta$-endotoxins in $10 \%$ SDSPAGE gels. The molecular weight of the Cry proteins was determined by comparing with protein markers of known molecular weight (BIO-RAD 161-0304).

DNA extractions: The protocol for DNA extraction described by Chen and Kuo (1993) was used and DNA concentrations were estimated by fluorometry at $280 \mathrm{~nm}$ (Quantech fluorometer, model FM1 109535).

PCR analyses: The general primer for the cry1, cry3-7, cry5, cry8, cry11, cry12, cry14, and $c y t$ genes and specific primer for crylAa, crylAb, crylAc, crylAd, crylB, crylC, crylD, crylE, crylF (Bravo et al., 1998), also vip1, vip2, vip3 (A. Bravo, personal communication) and the general primer for cry2 gene (Ben-Dov

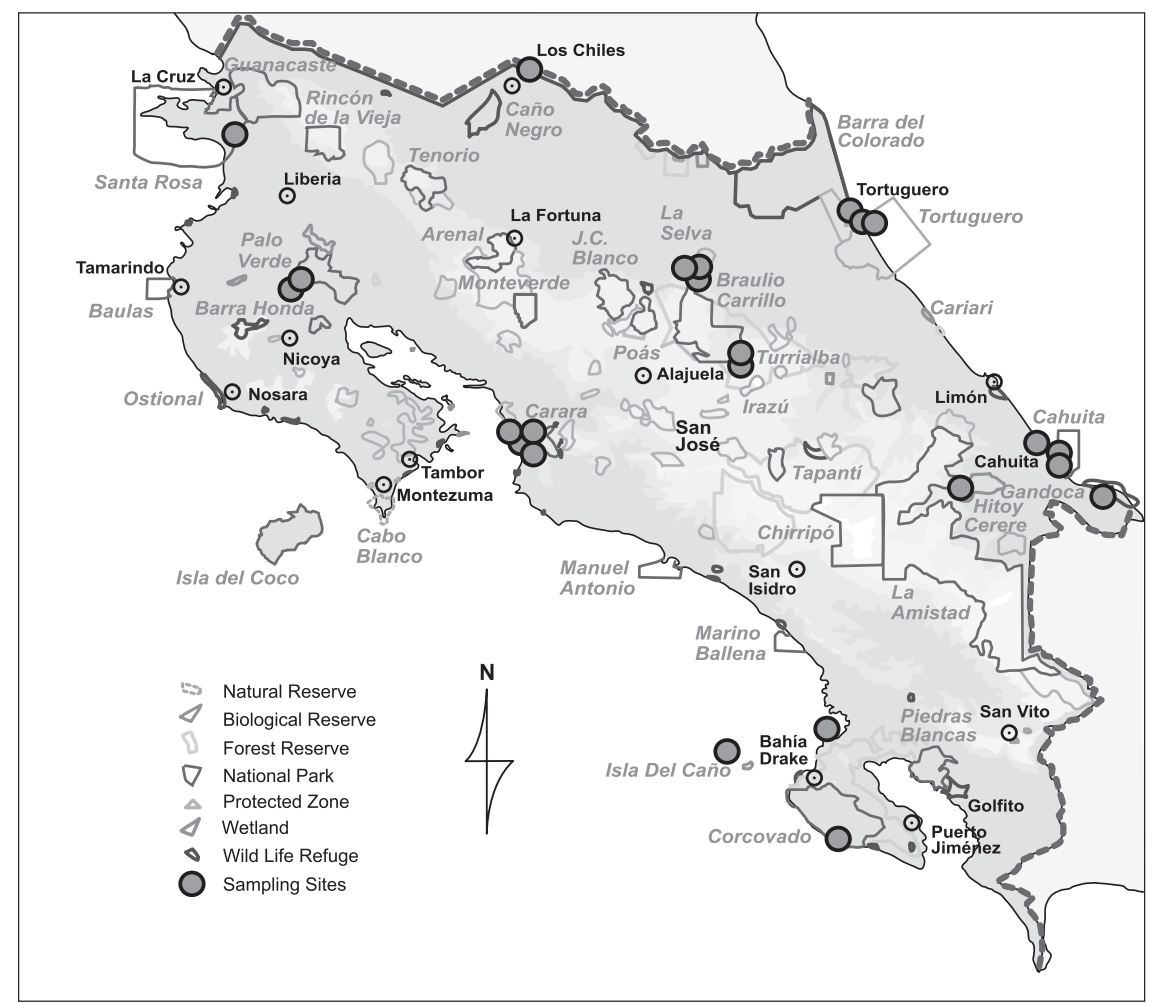

Fig. 1. Costa Rica: Bacillus thuringiensis collection localities. 
et al. 1997) were used. For the PCR the following conditions were used: $25 \mathrm{mM} \mathrm{MgCl}{ }_{2}, 10 \mathrm{x}$ buffer, $10 \mathrm{mM}$ dNTPs, $20 \mu \mathrm{M}$ each primer, 2.5 $\mathrm{U}$ Taq polymerase and 5 to $20 \mathrm{ng}$ of DNA. The PCR program was: one denaturing cycle of two min. at $95^{\circ} \mathrm{C}, 30$ cycles of one min. at $95^{\circ} \mathrm{C}$, one min. at $48-54^{\circ} \mathrm{C}$, one min. at $72^{\circ} \mathrm{C}$, and a final extension cycle of $5 \mathrm{~min}$. at $72^{\circ} \mathrm{C}$. PCR products were analyzed by gel electrophoresis in $1 \%(\mathrm{w} /$ v) agarose gels. The reference strains HD-137, HD-1, Btt, HD-916, were obtained from the Bacillus Genetic Center Stock; Department of Biochemistry (Ohio State University).

\section{RESULTS}

A total of $146 \mathrm{Bt}$ strains were isolated from environmental samples from diverse natural ecosystems collected from 9 of the 12 life zones of Costa Rica. Bt strains were obtained from $60 \%$ of the samples. It was possible to recover $B t$ strains with an efficiency of $71 \%, 63 \%, 61 \%$ and $54 \%$ from soil samples, fresh leaves, other substrates and leaf litter respectively. $B t$ was isolated in $65 \%$ of the samples collected in the humid tropical forest of the national parks (Braulio Carrillo, Gandoca Manzanillo, Sierpe, Hitoy Cerere, and Cahuita), in 59\% of the samples collected in the dry tropical forest (Parque Nacional Marino las Baulas, Palo Verde and Santa Rosa). In the very humid tropical forest (Tortuguero) Bt was isolated in $75 \%$ of the samples and in the very humid tropical forest transition perhumid (Carara) was found in 69\% of the samples (Fig. 1). Statistical analysis $\left(\chi^{2}\right)$ indicated no significant differences in relation to the efficiency of $B t$ strain recovery from different life zones.

The microscopic observation of the crystals showed high diversity in the morphology, number as well as in the size of the parasporal inclusions. Small, medium and large oval crystals were frequently found. Also, some strains presented small and large bipyramidal as well as irregular crystals (Fig. 2). This diversity was reflected also in the presence of different crystal inclusions, since some strains produce crystals

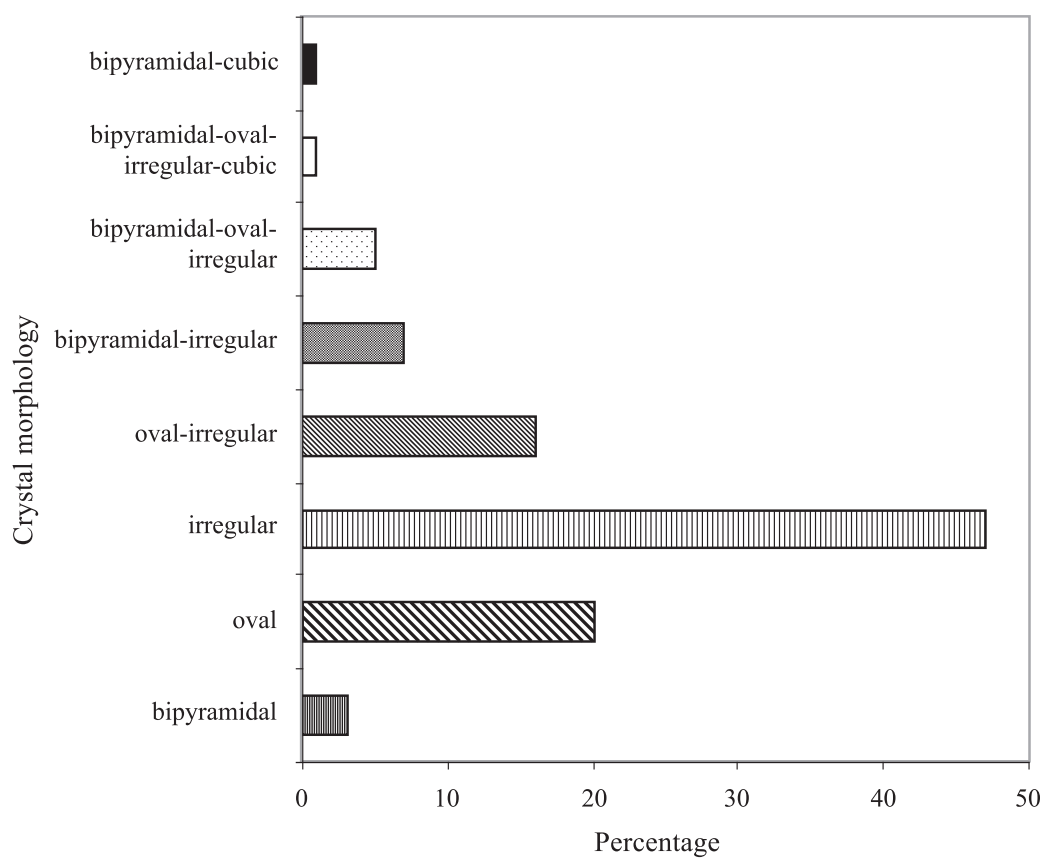

Fig. 2. Percentage distribution of crystal morphologies of the Costa Rican Bacillusthuringiensis strain collection, isolated from natural ecosystems. 
with several morphologies, whereas others show only one type of crystal. Most strains presented more than one crystal morphology, for example up to six different crystals in the same strain. Figure 2 shows the different crystal morphologies, the irregular being the most common $(47 \%)$, followed by the oval $(20 \%)$. Twenty-four strains (16\%) showed a combination of both. The combination of bipyramidal and cubical crystals was rare.

No correlation was found when crystal morphology and isolation sites were compared. However, strains isolated from Braulio Carrillo, Tortuguero and Cahuita, presented abundant irregular crystals. One of the few strains that presented large cubic, oval and bipyramidal crystals was isolated from Tortuguero. On the other hand, more than $60 \%$ of the isolated strains of Térraba-Sierpe, and Hitoy-Cerere presented medium oval crystals. Several strains isolated from Gandoca-Manzanillo, Palo Verde and Carara presented mainly combinations of oval and irregular crystals. The greatest diversity in morphologies was observed in those from Santa Rosa, Llanos del Río Medio Queso and Parque Marino las Baulas.

The collection was also characterized by SDS-PAGE to determine the number and molecular weight (MW) of the Cry proteins. The analyses showed diverse electrophoretic patterns, with MWs in the range of 20 to $160 \mathrm{kDa}$ (Appendix 1). Strains isolated from Parque Marino las Baulas presented very different $\delta$-endotoxin profiles. Strain CIBCM-134 expressed proteins of 130 and $60 \mathrm{kDa}$, while the CIBCM-142, produced proteins of 20 or 40 $\mathrm{kDa}$. These strains presented small and large bipyramidal crystals respectively. There was no correlation between the morphology of the inclusion body and the MW of the $\delta$-endotoxins (Appendix 1). The irregular and the oval crystals presented the greatest diversity in the MW of their Cry proteins, while the bipyramidal crystals often showed high MW $\delta$-endotoxins $(140$ or $120 \mathrm{kDa})$. For example, the CIBCM251 strain with oval crystals presented Cry proteins of 90 or $100 \mathrm{kDa}$. In addition, there was no correlation between crystal morphology and the number of Cry proteins detected. For example, one strain from Braulio Carrillo with pleomorphic crystals showed proteins of 60, 70 and $100 \mathrm{kDa}$, while another with the same crystal morphology isolated from Santa Rosa contained a single polypeptide of $70 \mathrm{kDa}$. It should be pointed out that strains that showed four $\delta$-endotoxins in the gel also presented several crystals, while strains with single crystal morphology presented three Cry proteins (for example CIBCM-251).

The characterization of the collection by PCR showed that cry2 and vip3 genes were found in 87 and 85 strains respectively. Thirtyone strains amplified with the general primer cry1, 14 with cry3-7, 12 with $c r y 8,11$ harbored the cry 11 gene and finally 13 amplified with the cyt general primer. Amplification with the general primers for the cry5, cry 12 , cry 14 and vipl genes was not detected. Also it is important to mention that 24 strains did not amplify with any of the primers used. Figure 3 shows the distribution of the genes of the collection according to forest type. All types of forest contained Bt strains with same type of genes, but their frequencies differed. Nevertheless, the dry tropical forest showed the greatest number of strains with cry2, cry3-7, cry 8 and cyt genes. Several strains presented great diversity of cry genes, for example CIBCM-165 amplified with cry1, cry2, cry11, cyt and vip3 genes. Also CIBCM-154 amplify with the primers for cryl, cry2, cry3-7 and cry8 genes (Appendix 1).

Strains that amplified with the cryl general primer were further analyzed with specific primers for different subfamilies. Twenty-two strains presented at least one gene of the crylA subfamily, 11 strains showed the crylD and four the crylB gene (Appendix 1). The crylE gene was scarce (only two strains). None of the $B t$ strains of this collection contained the crylC or $c r y l F$ genes. On the other hand, eight strains did not amplified with any of specific primers tested for cryl subfamilies. A total of 13 different genetic profiles were found for the cryl family (Appendix 1). 


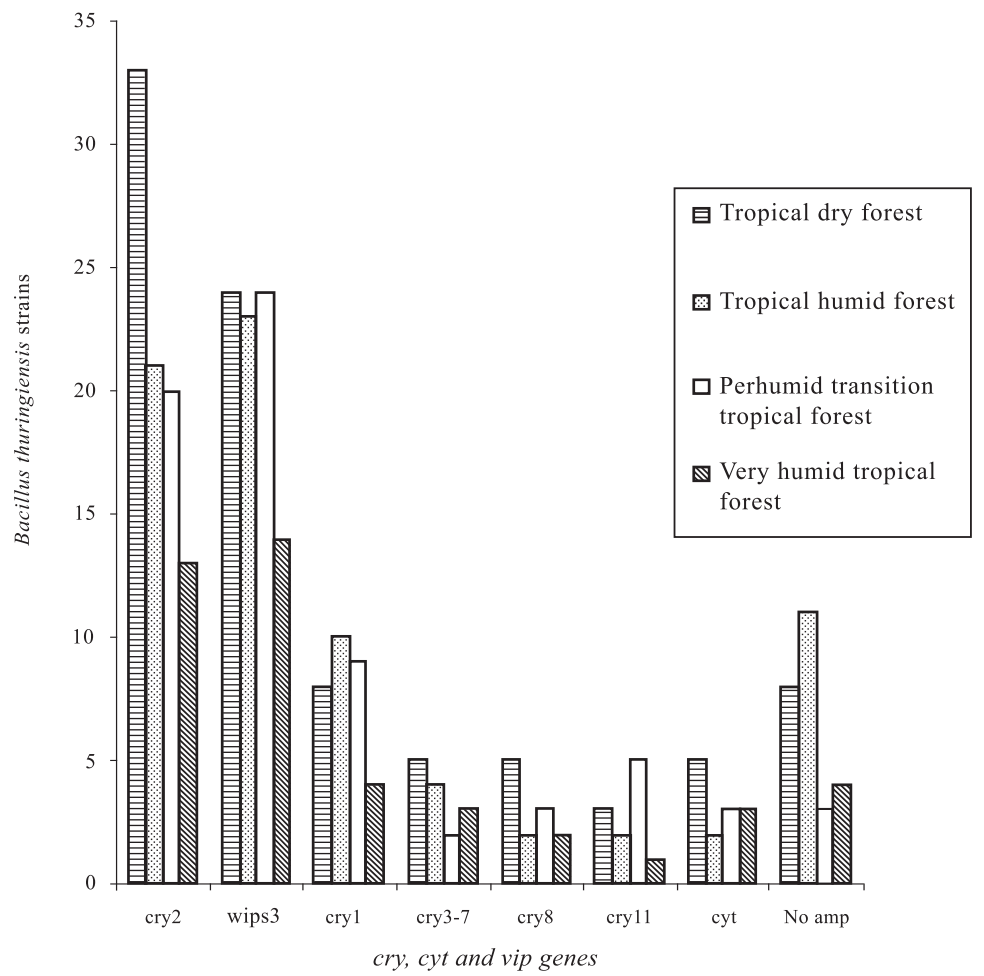

Fig. 3. Distribution of cry, cyt and vip genes of the Costa Rican Bacillus thuringiensis strain collection, according to forest type.

\section{DISCUSSION}

A collection of 146 strains of Bacillus thuringiensis was obtained from environmental samples derived from diverse natural ecosystems of Costa Rica. This research corroborated the broad distribution of $B t$ in different microhabitats. Isolation efficiency was of $60 \%$, a very similar figure to that reported by other authors (Martin and Travers 1989). It is important to indicate that the dry tropical forest seems to present the greatest diversity, not only in crystal morphologies but also in the insecticidal protein genes.

This collection showed great diversity in morphology, size and number of parasporal inclusions. It was not possible to establish a correlation between crystal morphology and the origin of the strain. Although it was possible to isolate strains from different areas with similar crystal morphologies, it is interesting to emphasize that some strains from specific sites presented rare morphologies, for example the CIBCM-142 from the Parque Marino las Baulas showed long bipyramidal crystals and CIBCM296 from Tortuguero had large cubic crystals.

Diversity in crystal protein patterns was also revealed by electrophoresis. Our results differed from those obtained in strains isolated from agricultural ecosystems (Víquez 2000). It was reported previously that the characterization by SDS-PAGE of these strains showed homogeneous $\delta$-endotoxin profiles that presented mainly two bands, one of 130 and another of $60 \mathrm{kDa}$. The strains isolated from natural ecosystems showed, in addition, other proteins of 20, 40, 70, 80 and $90 \mathrm{kDa}$. Similar results were reported by Bravo et al. (1998) who found that the strains with novel Cry proteins were isolated from Mexican humid tropical forests. 
Our results and those obtained by Bravo et al. (1998) showed that natural ecosystems with more insect species present a greater diversity of $B t$ strains. Since a co-evolution of $B t$ strains and their susceptible insect hosts has been proposed (Apoyolo et al. 1995), prospection of Bt strains in diverse natural ecosystems should be consider as an efficient strategy for the identification of new Cry proteins with novel specificities.

The $B t$ crystals of some strains are made up of a single protein, for example Bt var kurstaki HD-73 that contained only the Cry1Ac protein. Some of the characterized strains of this collection, showed a single protein in the SDS-PAGE, suggesting that their crystals are comprised of a single protein, or by two or more proteins with the same molecular weight. Nevertheless, one type of crystal could be constituted by different proteins as in the strain Bt var morrisoni, where proteins Cry4, Cry1A and Cyt form several inclusions covered by a common membrane (Ibarra et al. 1986). In other strains, like the HD-1, several proteins (Cry1Aa, Cry1Ab, and Cry1Ac) form a single crystal (Hofte et al. 1998). Abundant oval crystals were observed in the strain CIBCM-251, but when analyzed by electrophoresis, three $\delta$-endotoxin of 60,90 and $100 \mathrm{kDa}$ were detected. This complexity was observed in some of the strains that synthesize single bipyramidal crystals, for example CIBCM-281 that presented three $\delta$-endotoxins with different MWs.

It was also noticed that strains with bipyramidal crystals frequently presented two proteins, one of high MW of 120 or $140 \mathrm{kDa}$ and another of 65 or $60 \mathrm{kDa}$. These proteins could be the protoxin and the active toxin respectively. As $B t$ regulates the synthesis of proteases that can process protoxin to toxins (Rukmini et al. 2000), the proteolysis could imply reduction of activity, since the $\delta$-endotoxins are less stable than protoxin or, on the other hand, would permit the bacteria to respond faster because the insect is ingesting the activated toxin.

Some of the $\delta$-endotoxins of low MW (30$40 \mathrm{kDa}$ ) detected in the gels could be either Cyt proteins or binary toxins. In addition to the Cry proteins, it is probable that some of strains produce Vip proteins, since a high percentage of the strains amplified with Vip3 primers. Unfortunately it was not possible to determine if those proteins were expressed during the vegetative phase and secreted to the medium.

The most common cry genes found in nature are those within the cryl family (Porcar and Juárez-Pérez 2003). In our collection strains containing cryl genes were not so abundant (20\%). The cry 2 gene was the most frequently found, like in other collections (Ibarra, personal communication). It has been reported that these proteins have MWs of 70 to $75 \mathrm{kDa}$. Table 1 shows that several strains of the collection expressed a protein of $70 \mathrm{kDa}$ that could be the Cry2 protein, a protein toxic for insects of the Lepidoptera and Diptera orders. The high frequency of these proteins in several $B t$ strains could have permitted them to extend the host range.

The second most frequent gene of this collection was vip3, (58 \%). Estruch et al. (1996) found this gene in only $15 \%$ of the strains of their collection. Arrieta et al. (2004) also reported a widespread distribution of this gene in strains isolated from Costa Rican agricultural ecosystems. In contrast, the vipl gene was not detected in this collection and only one strain presented the vip2 gene. Different results were obtained in a Costa Rican collection isolated from coffee plantations where the frequency of the vip2 gene was higher (Arrieta et al. 2004).

The occurrence of cryl gene varies greatly among different $B t$ collections. For example cry $1 A$ genes were frequently present in more than $50 \%$ of the strains, whereas other genes of the subfamily, such as crylE and crylF, were less frequent. However there are some exceptions, such as the high frequency of crylE in a Chinese collection (Porcar and Juárez-Pérez 2003).

Several reports showed a high frequency of certain combinations of cryl genes, for example the linkage of the cry $1 C$ and crylD genes (Bravo et al. 1998, Ferrandis et al. 1999, Hongyu et al. 2000). This crylC and crylD linkage may be explained by their location on the same replicon (Sanchis et al. 1988). 
However, eleven $B t$ strains of the Costa Rican collection contained only the cry $1 D$. Ferrandis et al. (1999) suggested that the absence of the cry $1 C$ gene might be explained by a deletion or negative selection of the crylC gene from an ancestral crylC-cry $1 D$ linkage.

In summary, the diversity of $B t$ toxins indicate that the collection analyzed has great potential for the control of different species of insect pests of economic importance. Strains with a diversity of genes for the control of lepidopterans, dipterans and coleopterans were found. It is interesting to mention that this $B t$ collection obtained from natural ecosystems presented greater diversity of cry genes in comparison to other collections isolated from Costa Rican agricultural ecosystems (Arrieta et al. 2004, Mora and Espinoza 2005). The characterization of this collection will offer very useful information for the selection of $B t$ strains with particular Cry protein profiles to be evaluated for their toxicity against specific insect pests of important food crops.

\section{ACKNOWLEDGMENTS}

We thank César Rodríguez for his collaboration during the initial phases of this project and to acknowledge the Fundación para la Cooperación Costa Rica-Estados Unidos de América (CR.USA) and the Programa de Cooperación del Gobierno de México for the financial support of the project. We also want to express our gratitude to CYTED for supporting the Bt-network from which our laboratory is part and to the Sistema Nacional de Areas de Conservación for the access to the environmental samples. Finally, we thank Alejandra Bravo (Institute of Biotechnology, UNAM-Mexico) for providing us with the reference strains HD137, HD-1, Btt, HD-916.

\section{RESUMEN}

Como los ecosistemas naturales de Costa Rica figuran entre los más diversos del mundo, se propuso aislar la bacteria entomopatógena Bacillus thuringiensis $(B t)$ con el fin de conformar una colección de cepas y caracterizarlas molecularmente. Se obtuvieron 146 cepas a partir de muestras ambientales de diversas áreas protegidas, que incluían 9 de las 12 zonas de vida de Costa Rica. Se recobraron cepas del $71 \%, 63 \%, 61 \%$ y $54 \%$ de las muestras de suelo, hojas frescas, otros sustratos y hojarasca respectivamente. Se aisló Bt del 65\% de las muestras del bosque tropical húmedo, un $59 \%$ de las muestras del bosque tropical seco. Del bosque tropical muy húmedo se aisló Bt del 75\% de las muestras y finalmente del bosque tropical muy húmedo transición perhúmedo se encontró en el $69 \%$ de las muestras. Las cepas se caracterizaron según la morfología de los cuerpos paraesporales de inclusión, el peso molecular de las $\delta$-endotoxinas y de genes cry, cyt y vip que contenían. Las cepas exhibieron cristales de diferente morfología, tamaño y número: irregulares, ovales, bipiramidales, cúbicos o mezclas de uno u otro. No se encontró correlación al comparar la forma de los cristales con el sitio de origen de la cepa. El análisis proteico de las mezclas de esporas y cristales mostró que las cepas contenían $\delta$-endotoxinas de 20 a $160 \mathrm{kDa}$. El 66 por ciento de las cepas amplificaron con los imprimadores específicos para el gen cry2, 54\% con vip3, $20 \%$ con el cry $1,9 \%$ con el cry3-cry 7 y $8 \%$ con el gen cry8. Los genes cry11 y cyt se encontraron en el $8 \%$ y $7 \%$ de las cepas respectivamente. Veinticuato cepas no amplificaron con los imprimadores utilizados por lo que podrían contener genes novedosos. Las cepas que contenían el gen cryl se amplificaron posteriormente con imprimadores específicos para la subfamilia de dicho gen, obteniéndose 13 perfiles diferentes. En síntesis, la diversidad genética de las cepas sugiere que la colección tiene un gran potencial para el control de diferentes especies de insectos de importancia económica en la agricultura y en salud pública. El análisis toxicológico de las cepas mediante bioensayos con insectos plaga proveerá información muy útil acerca del uso potencial de estas cepas para la formulación de bioinsecticida. Asimismo, lo genes cry y vip podrían utilizarse para, mediante ingeniería genética, conferir resistencia a los cultivos.

Palabras clave: Bacillus thuringiensis, cristales, genes cry, vip, $\delta$-endotoxinas, parques nacionales, Costa Rica.

\section{REFERENCES}

Apoyolo, C.I., L. Drif, J.M. Vassal, H. Debarjac, J.P. Bossy, F. Leclant \& R. Frutos. 1995. Isolation of multiple subspecies of Bacillus thuringiensis from a population ofthe European sunflower moth, Homoeosoma nebulella. Appl. Environ. Microbiol. 61: 4343-4347.

Aronson, A.I., W. Beckman \& P. Dunn. 1986. Bacillus thuringiensis and related insect pathogens. Microbiol. Rev. 50: 1-24. 
Arrieta, G., A. Hernández \& A.M. Espinoza. 2004. Diversity of Bacillus thuringiensis strains isolated from coffee plantations infested with the coffee berry borer Hypothenemus hampei Ferrari. Rev. Biol. Trop. 52: 757-764.

Ben-Dov, E., A. Zaritsky, E. Dahan, Z. Barak, R. Sinai, R. Manasherob, A. Khamraev, E. Troitskaya, A. Dubitsky, N. Berezina \& Y. Margalith. 1997. Extended screening by PCR for seven cry-group genes from field-collected strains of Bacillus thuringiensis. Appl. Environ. Microbiol. 63: 4883-4890.

Betz F., B.G. Hammond \& R.L. Fuchs. 2000. Safety and advantages of Bacillus thuringiensis protected plants to control insects pest. Reg. Tox. Pharm. 32: 156-173.

Bravo, A., S. Sarabia, L. López, H. Ontiveros, C. Abarca, A. Ortiz, M. Ortiz, L. Lina, J. Villalobos, G. Peña, V.G. Noez, M. Soberon \& R. Quintero. 1998. Characterization of cry genes in a Mexican Bacillus thuringiensis strain collection. Appl. Environ. Microbiol. 64: 4965-4972.

Bull, A.T., M. Goodfellow \& J.H. Slater. 1992. Biodiversity as a source of innovation in biotechnology. Ann. Rev. Microbiol. 46: 219-252.

Chen, W. \& T. Kuo.1993. A simple and rapid method for the preparation of gram-negative bacterial genomic DNA. Nucl. Acids Res. 21: 2260.

Crickmore, N., D.R. Zeigler, J. Feitelson, E.J. Schnepf Van Rie, D. Lereclus, J. Baum \& D.H. Dean. 1998. Revision of the nomenclature for the Bacillus thuringiensis pesticidal crystal proteins. Microbiolol. Mol. Rev. 62: 807-813.

Estruch J.J., G.W. Warren, G.J. Mullins, G.C. Nye, J.A. Craig \& M.G. Koziel. 1996. Vip3A, a novel Bacillus thuringiensis vegetative insecticidal protein with a wide spectum of activities against lepidopteran insects. Proc. Natl. Acad. Sci. USA 93: 5389-5394.

Ferrandis, M.D., V.M. Juárez-Pérez, R. Frutos, Y. Bel \& J. Ferré. 1999. Distribution of cryl, cryII, and cryV genes within Bacillus thuringiensis isolates from Spain. System Appl. Microbiol. 22: 179-185.

Hofte, H. \& H.R. Whiteley. 1989. Insecticidal crystal proteins of Bacillus thuringiensis. Microbiol. Rev. 53: $242-255$

Hongyu, Z., Y. Ziniu \& D. Wangxi. 2000. Composition and ecological distribution of Cry proteins and their genotypes of Bacillus thuringiensis isolates from warehouses in China. J. Invertebr. Pathol. 76: 191-197.
Ibarra, J. E. \& B.A. Federici. 1986. Parasporal bodies of Bacillus thuringiensis ssp. morrisoni (PG-14) and Bacillus thuringiensis ssp. israeliensis are similar in protein composition and toxicity. FEMS Microbiol. Lett. 34: 78-84.

James, C. 2002. Global review of commercialized transgenic crops: 2001 feature: Bt cotton. International Service For The Acquisition of Agri-Biotech Application. 26.

Martin, P.A. \& R.S. Travers. 1989. Worldwide abundance and distribution of Bacillus thurigniensis isolates. Appl. Environ. Microbiol. 55: 2437-2442.

Martínez, C. 2002. Biological and genetic characterization of Bacillus thuringiensis strains toxic against Helicoverpa armigera. 573 p. UPNA. Pamplona.

Mora, R. \& A.M. Espinoza. 2005. Isolation and characterization of Bacillus thuringiensis strains isolated from insects of the order Homoptera. Rev. Biol. Trop. (Submitted).

Obando. 2002. Biodiversity in Costa Rica: state of knowledge and management. INBio-SINAC. San José, Costa Rica.

Porcar, M. \& V. Juárez-Pérez. 2003. PCR-based identification of Bacillus thuringiensis pesticidal crystal genes. FEMS Microbiol. Rev. 26: 419-432.

Ross, M.A. \& C.A. Lembi. 1985. Applied Weed Science. 340 pages. McMillanNew York, New York, USA.

Rukmini, V., Y. R. Reddy \& G. Venkateswerlu. 2000. Bacillus thuringiensis crystal $\delta$-endotoxin: Role of proteases in the convertion of protoxin to toxin. Biochimie 82: 109-116.

Samsonov, P., R.I. Padrón, C. Pardo, J. Cabrera \& G.A. De la Riva. 1997. Bacillus thuringiensis from biodiversity to biotechnology. J. Industri. Microbiol. Biotech. 19: 202-219.

Sanchis, V., D. Lereclus, G. Menou, J. Chaufaux \& M.M. Lecadet. 1988. Multiplicity of $\delta$-endotoxin genes with different specificities in Bacillus thuringiensis aizawai. Mol. Microbiol. 2: 393-404.

Travers, R.S., P.A.W. Martin \& C.F. Reichelderfer. 1987. Selective process for efficient isolation of soil Bacillus spp. Appl. Environ. Microbiol. 53: 1263-1266.

Víquez, A. 2000. Búsqueda y caracterización de proteínas biopesticidas novedosas a partir de cepas de Bacillus thuringiensis aisladas de ecosistemas costarricenses. Tesis Facultad de Microbiología, Universidad de Costa Rica. 
APPENDIX 1

Summary of the characterization of the Costa Rican Bacillus thuringiensis strain collection isolated from natural ecosystems, according to crystal morphology, molecular weight of the $\delta$-endotoxin and insecticidal genes

Bacillus

thuringiensis strains

\begin{tabular}{|c|c|}
\hline CIBCM-1 & Braulio Carrillo \\
\hline CIBCM-4 & Braulio Carrillo \\
\hline CIBCM-5 & Braulio Carrillo \\
\hline CIBCM-7 & Braulio Carrillo \\
\hline CIBCM-8 & Braulio Carrillo \\
\hline CIBCM-9 & Braulio Carrillo \\
\hline CIBCM-11 & Braulio Carrillo \\
\hline CIBCM-12 & Braulio Carrillo \\
\hline CIBCM-13 & Braulio Carrillo \\
\hline CIBCM-15 & Braulio Carrillo \\
\hline CIBCM-16 & Braulio Carrillo \\
\hline CIBCM-17 & Braulio Carrillo \\
\hline CIBCM-18 & Braulio Carrillo \\
\hline CIBCM-19 & Braulio Carrillo \\
\hline CIBCM-63 & Carara \\
\hline CIBCM-64 & Carara \\
\hline CIBCM-65 & Carara \\
\hline CIBCM-66 & Carara \\
\hline CIBCM-67 & Carara \\
\hline CIBCM-68 & Carara \\
\hline CIBCM-69 & Carara \\
\hline CIBCM-70 & Carara \\
\hline CIBCM-74 & Carara \\
\hline CIBCM-75 & Carara \\
\hline CIBCM-76 & Carara \\
\hline CIBCM-80 & Carara \\
\hline CIBCM-81 & Carara \\
\hline
\end{tabular}

$\begin{array}{cc}\begin{array}{c}\text { Enviromental } \\ \text { sample }\end{array} & \begin{array}{c}\text { Crystal } \\ \text { morphology }\end{array}\end{array}$

Molecular weight of Cry \& Cyt proteins $(\mathrm{kDa})$

Cry, cyt and vip genes

$$
65,50,45
$$$$
110,10060
$$$$
125,70,50
$$$$
70,30
$$

60,50

$60,45,30$

$65,50,40$

65

$$
65,44
$$

$110,90,70$

$130,75,60$

$$
75,60
$$

$100,70,60$

85,65

Other substrate

$\mathrm{Bi}, \mathrm{Ir}$

Fresh leaves

$\mathrm{Bi}, \mathrm{Ir}$

Other substrate

Bi, Ir

Other substrate

Bi

Other substrate

Ir

Other substrate

Ir

Other substrate

Bi, Ir

$$
\text { Soil }
$$

Bi, Ir

Other substrate

$\mathrm{Bi}, \mathrm{Ov}, \mathrm{Ir}$

$$
\text { Soil }
$$

Soil

Leaf litter

Ov, Ir

Soil

Soil
Bi

Ov

ii

Ov

Ov
$140,110,70$

$90,72,45$

$140,85,65$

$85,65,56$

$70,60,52$

$140,75,68,45$

81,60

$110,75,45$

45, 20

85,66

$85,66,56$

85,65

$82,55,40$

$$
\begin{gathered}
\text { cry2, vip3 } \\
\text { N amp } \\
\text { cry1, cry2, vip3 } \\
\text { cry2, vip3 } \\
\text { N amp }
\end{gathered}
$$

vip3 cry2, vip3

vip3

$$
N a m p
$$

$$
N a m p
$$

cry1, cry2, vip3

$$
\text { cry2, vip3 }
$$

cry1, cry2, vip3

cry2, vip3, cry11

cry1, cry2, vip3, cry8

cry2, cry8, vip3

$$
\text { cry1, vip3 }
$$

cry2, vip3

cry2, cry11, vip3

cry1, cry2, vip3

cry1, cry2, vip3

cry 2

cry2, vip3

cry2, cry11, vip3

cry2,vip3

cyt, vip3

$$
\text { cryl, cry } 2
$$


APPENDIX 1 (continued...)

Summary of the characterization of the Costa Rican Bacillus thuringiensis strain collection isolated from natural ecosystems, according to crystal morphology, molecular weight of the $\delta$-endotoxin and insecticidal genes

$$
\begin{gathered}
\text { Bacillus } \\
\text { thuringiensis } \\
\text { strains }
\end{gathered}
$$

CIBCM-85
CIBCM-90
CIBCM-92
CIBCM-94
CIBCM-97
CIBCM-101
CIBCM-103
CIBCM-105
CIBCM-107(A)
CIBCM-112
CIBCM-122
CIBCM-127
CIBCM-128
CIBCM-129
CIBCM-131
CIBCM-134

CIBCM-137

CIBCM-142

CIBCM-147

CIBCM-150

CIBCM-151

CIBCM-153

CIBCM-154

CIBCM-155

CIBCM-156

CIBCM-161
Protected area

$\begin{array}{cc}\begin{array}{c}\text { Enviromental } \\ \text { sample }\end{array} & \begin{array}{c}\text { Crystal } \\ \text { morphology }\end{array}\end{array}$

$$
\text { Carara }
$$

Carara

Carara

Carara

Carara

Carara

Carara

Carara

Carara

Carara

Carara

Marino las Baulas

Marino las Baulas

Marino las Baulas

Marino las Baulas

Marino las Baulas

Marino las Baulas

Marino las Baulas

Marino las Baulas

Gandoca-Manzanillo

Gandoca-Manzanillo

Gandoca-Manzanillo

Gandoca-Manzanillo

Gandoca-Manzanillo

Gandoca-Manzanillo

Gandoca-Manzanillo

Medio-Queso

\section{Leaf litter}

Other substrate

Leaf litter

Leaf litter

Soil

Soil

Soil

Soil

Soil

Leaf litter

Leaf litter

Soil

Leaf litter

Soil

Soil

Leaf litter

$\mathrm{Bi}, \mathrm{Ov}, \mathrm{Ir}, \mathrm{Cu}$

Soil

Leaf litter

Ov

Ov

Soil

$\mathrm{Bi}, \mathrm{Ov}$

Soil

Ov, Ir

Fresh leaves

Ov

Soil

Ov, Ir

Fresh leaves

Ov, Ir

Soil

Soil

Leaf litter

Soil

Ov, Ir

Ir

Ir

Ov
Molecular weight of Cry \& Cyt proteins $(\mathrm{kDa})$

Cry, cyt and vip genes

$$
55,40
$$

$$
\text { Namp }
$$

$80,72,50,35$

cry1, cry2, vip3

$80,67,55,40$

cry11, cyt

$95,65,40$

cry2, cry11, vip3

$70,60,45$

cry2, cry11, vip2, vip3
80,50

$80,55,45$

$90,55,50,40$

$100,70,60$

$120,80,60$

$65,55,40$

$85,70,60$

$120,80,40$

$100,90,70,45$

$120,80,40$

130,60

120,70

80, 70, 45

$140,40,20$

$70,62,52$

$70,60,40$

$60,50,35$

$65,55,45$

vip3

cry2, vip3

vip3

cry2, vip3

cry2, vip3

$N$ amp

cry 8

cry 2

cry2, cry 8

cry 2

cry1, cry2, vip3

vip3

cry 2

cryl

vip3

$N$ amp

vip3

$80,75,65,50$

cry1, cry2, cry3-7, cry 8

80,64

cry $1, \operatorname{cry} 2, \operatorname{cry} 8$

$130,90,70,60$

cry1, cry2, vip3

80,65

cry 2 
APPENDIX 1 (continued...)

Summary of the characterization of the Costa Rican Bacillus thuringiensis strain collection isolated from natural ecosystems, according to crystal morphology, molecular weight of the $\delta$-endotoxin and insecticidal genes

Bacillus thuringiensis strains

\section{CIBCM-163}

CIBCM-165

CIBCM-166

CIBCM-167

CIBCM-168

CIBCM-180

CIBCM-187

CIBCM-188

CIBCM-189

CIBCM-191

CIBCM-193

CIBCM-234

CIBCM-246

CIBCM-250

CIBCM-251

CIBCM-252

CIBCM-254

CIBCM-259

CIBCM-260

CIBCM-261

CIBCM-263

CIBCM-264

CIBCM-265

CIBCM-267

CIBCM-269

CIBCM-270
Protected area

Medio-Queso

Medio-Queso

Medio-Queso

Medio-Queso

Medio-Queso

Medio-Queso

Palo Verde

Palo Verde

Palo Verde

Palo Verde

Palo Verde

Palo Verde

Palo Verde

Palo Verde

Palo Verde

Palo Verde

Palo Verde

Santa Rosa

Santa Rosa

Santa Rosa

Santa Rosa

Santa Rosa

Santa Rosa

Santa Rosa

Santa Rosa

Santa Rosa

$$
\begin{array}{cc}
\text { Enviromental } & \text { Crystal } \\
\text { sample } & \text { morphology }
\end{array}
$$

Soil

Other substrate

Bi, Ir

Other substrate

$\mathrm{Bi}, \mathrm{Ir}, \mathrm{Ov}, \mathrm{Cu}$

Soil

$\mathrm{Bi}, \mathrm{Ov}$, Ir

140,65

$140,110,90,73$

Ov, Ir

Ov, Ir

Soil

Fresh leaves

Ov

Ov, Ir

Ov, Ir

Soil

Ov

Fresh leaves

Ov

Soil

Soil

Leaf litter

Fresh leaves

Soil

Fresh leaves

Soil

Leaf litter

Fresh leaves

Soil

Fresh leaves

Soil

Fresh leaves

Soil

Fresh leaves of Cry \& Cyt proteins $(\mathrm{kDa})$

$$
67,55,40
$$

$110,85,70,40$

$130,95,65$

$125,100,30$

$140,70,50$

$100,70,40$

$125,105,40$

$100,90,50,30$

$85,45,30$

80,50

$70,50,40$

$100,70,60,45$

100, 90

$70,60,50$

$120,90,50$

$100,90,50$

$105,90,60,40$

$110,95,70$

$95,70,40$

$80,7240,30$

$90,62,55$

$125,90,55$

$65,55,30$

Ov

$100,90,45$
Molecular weight

Cry, cyt and vip genes

cry1, cry2, cry8, vip3

$$
\begin{gathered}
\text { N amp } \\
\text { cry1, cry2, cry11, } \\
\text { cyt, vip3 } \\
\text { cry1, cry2, vip3 }
\end{gathered}
$$

cry1, vip3

$$
N \text { amp }
$$

cry3-7, cyt

cry2, vip3

cry2, cry11, cyt, vip3

cry 11, cyt, vip3

cry11, vip3

cry 2, cry $3-7$

N amp

cry 2

vip3

cry 2

cry 2

cry2, cry3-7

cry2, vip3

cyt, vip3

cry2, vip3

cry 2

$N$ amp

$N$ amp

$N$ amp

cry2, vip3 
APPENDIX 1 (continued...)

Summary of the characterization of the Costa Rican Bacillus thuringiensis strain collection isolated from natural ecosystems, according to crystal morphology, molecular weight of the $\delta$-endotoxin and insecticidal genes

Bacillus

thuringiensis strains

\begin{tabular}{|c|c|}
\hline CIBCM-271 & Santa Rosa \\
\hline CIBCM-273 & Santa Rosa \\
\hline CIBCM-274 & Santa Rosa \\
\hline CIBCM-275 & Santa Rosa \\
\hline CIBCM-276 & Santa Rosa \\
\hline CIBCM-277 & Santa Rosa \\
\hline CIBCM-279 & Santa Rosa \\
\hline CIBCM-281 & Santa Rosa \\
\hline CIBCM-285 & Hitoy-Cerere \\
\hline CIBCM-290 & Hitoy-Cerere \\
\hline CIBCM-292 & Hitoy-Cerere \\
\hline CIBCM-293 & Tortuguero \\
\hline CIBCM-294 & Tortuguero \\
\hline CIBCM-296 & Tortuguero \\
\hline CIBCM-300 & Tortuguero \\
\hline CIBCM-302 & Tortuguero \\
\hline CIBCM-303 & Tortuguero \\
\hline CIBCM-304 & Tortuguero \\
\hline CIBCM-305 & Tortuguero \\
\hline CIBCM-306 & Tortuguero \\
\hline CIBCM-307 & Tortuguero \\
\hline CIBCM-308 & Tortuguero \\
\hline CIBCM-310 & Tortuguero \\
\hline CIBCM-311 & Tortuguero \\
\hline CIBCM-314 & Tortuguero \\
\hline CIBCM-317 & Santa Rosa \\
\hline CIBCM-320 & Santa Rosa \\
\hline
\end{tabular}

$\begin{array}{cc}\begin{array}{c}\text { Enviromental } \\ \text { sample }\end{array} & \text { Crystal } \\ \text { morphology }\end{array}$

Molecular weight of Cry \& Cyt proteins $(\mathrm{kDa})$

$\begin{array}{cc}\text { Leaf litter } & \text { Ov } \\ \text { Soil } & \text { Ov, Ir } \\ \text { Soil } & \text { Ir } \\ \text { Fresh leaves } & \text { Ir } \\ \text { Soil } & \text { Ir } \\ \text { Leaf litter } & \text { Ir } \\ \text { Soil } & \text { Ov }\end{array}$

Fresh leaves $\quad \mathrm{Bi}$

$$
\text { Soil }
$$

Leaf litter

Leaf litter

Soil

Leaf litter

Soil

Leaf litter

Soil

Leaf litter

Fresh leaves

$\mathrm{Bi}, \mathrm{Ir}$

$$
\text { Soil }
$$

Leaf litter

Fresh leaves

Soil

Fresh leaves

Soil

Soil

Soil

Soil

$$
\begin{aligned}
& 100,90,40 \\
& 120,85,60
\end{aligned}
$$$$
70
$$

90,65

$100,90,50$

100,45

$50,40,20$

$130,65,40$

$90,80,75,60$

$$
\text { 90, } 40
$$

74,60

$90,65,60,45$

$100,90,52$

130,65

$100,90,50$

$110,85,65$

$65,60,40,35$

105, 65

60,40

40

60,40

$100,90,52,40$

$$
65,50
$$

$70,65,40$

$$
95,60
$$

$96,76,40$

$130,105,80,60$
Ir

Ov-Ir
Cry, cyt and vip genes

$$
\text { cry2, vip3 }
$$

cry1, cry2, vip3

cry2, cry3-7

cry2, cry3-7, cyt

$$
\begin{gathered}
\text { N amp } \\
\text { cry2, vip3 } \\
\text { cry2, vip3 }
\end{gathered}
$$

cryl

$$
N a m p
$$

cry3-7, vip3

cry2, cry3-7

cry2, cyt, vip3

vips 3

cry1, vips 3

cry 2

$N$ amp

cry2

cry1, cry2, cry3-7, vip3

cry 2

vip3

vip3

vip3

cry1, cry8, vip3

$$
\text { N amp }
$$

cry2, cry3-7
Namp

cry2, vip3 
APPENDIX 1 (continued...)

Summary of the characterization of the Costa Rican Bacillus thuringiensis strain collection isolated from natural ecosystems, according to crystal morphology, molecular weight of the $\delta$-endotoxin and insecticidal genes

Bacillus

thuringiensis strains

CIBCM-321

CIBCM-322

CIBCM-324

CIBCM-325

CIBCM-327

CIBCM-328

CIBCM-329

CIBCM-330

CIBCM-331

CIBCM-332

CIBCM-334

CIBCM-335

CIBCM-338

CIBCM-355

CIBCM-356

CIBCM-357

CIBCM-360

CIBCM-365

CIBCM-74(1)

CIBCM-74(2)

CIBCM-263(1)

CIBCM-294(1)

CIBCM-88(98)

CIBCM-89(98)

CIBCM-90(97)

CIBCM-96(57)

CIBCM-96(63)
Protected area

Santa Rosa

Santa Rosa

Santa Rosa

Santa Rosa

Cahuita

Cahuita

Cahuita

Cahuita

Cahuita

Cahuita

Cahuita

Cahuita

Cahuita

Tortuguero

Tortuguero

Tortuguero

Tortuguero

Tortuguero

Carara

Carara

Santa Rosa

Tortuguero

Carara

Carara

Carara

Santa Rosa

Santa Rosa

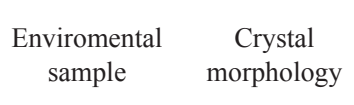

Leaf litter

Fresh leaves

Leaf litter

Fresh leaves

Soil

Leaf litter

Fresh leaves

Soil

Leaf litter

Fresh leaves

Leaf litter

Fresh leaves

Fresh leaves

Soil

Soil

Soil

Soil

Soil

Soil

Soil

Soil

Leaf litter

Soil

Leaf litter

Other substrate

Other substrate

Other substrate
$\mathrm{Bi}, \mathrm{Ov}, \mathrm{Ir}, \mathrm{Cu}$

Ov

$\mathrm{Bi}$, Ir

Ov, Ir

$\mathrm{Bi}, \mathrm{Ov}, \mathrm{Ir}, \mathrm{Cu}$

Ov, Ir

Ov

Ir

Ir

Ir

Ir

Bi

Bi

Ir

Ir

Ir

Ir

Ir

Bi, Ov, Ir

$65,57,50,30$

Bi, Ov, Ir

Ir

Bi -Ov-Ir

Ir

Ir

Ir

Ir

Ov, Ir

$60,44,30$

$140,80,65$

$90,65,40$

50,30

$100,80,65$

160,90

$86,63,44$

$130,110,75$

40, 35

$160,130,80$

135,65

$100,90,40$

$100,90,50$

65,50

65,55

65,55

$100,90,40$

$90,65,43$

53,40

$80,65,40$

$140,95,70$

$130,70,60$
Molecular weight of Cry \& Cyt proteins $(\mathrm{kDa})$

Cry, cyt and vip genes

cry2, vip3

cry1, cry2, cry8, vip3

vip3

$150,110,80,60$

$150,130,90,80$

$160,95,65,33$

cry1, cry2, vip3

cry11, cyt, vip3

cry2, vip3

cry2, vip3

cry 8

cry2, cry3-7, vip3

cry1, cry2, cry3-7, cry8, vip3

cryl

cry 2

$130,100,80,60$

cry1, cry2, vips3

cry2, vips 3

$N$ amp

cry3-7

cry 2

cry1, cry2, vips3 
APPENDIX 1 (continued...)

Summary of the characterization of the Costa Rican Bacillus thuringiensis strain collection isolated from natural ecosystems, according to crystal morphology, molecular weight of the $\delta$-endotoxin and insecticidal genes

\begin{tabular}{|c|c|c|c|c|c|}
\hline $\begin{array}{c}\text { Bacillus } \\
\text { thuringiensis } \\
\text { strains }\end{array}$ & Protected area & $\begin{array}{c}\text { Enviromental } \\
\text { sample }\end{array}$ & $\begin{array}{c}\text { Crystal } \\
\text { morphology }\end{array}$ & $\begin{array}{c}\text { Molecular weight } \\
\text { of Cry \& Cyt } \\
\text { proteins }(\mathrm{kDa})\end{array}$ & Cry, cyt and vip genes \\
\hline
\end{tabular}

$\begin{array}{lccccc}\text { CIBCM-96(72) } & \text { Santa Rosa } & \text { Other substrate } & \text { Ir } & 88,77,40 & \text { N amp } \\ \text { CIBCM-281(87) } & \text { Santa Rosa } & \text { Fresh leaves } & \text { Ir } & 60,45 & \text { cry2, cry8, vips3 } \\ \text { CIBCM-131(100) } & \text { Marino las Baulas } & \text { Soil } & \text { Ir } & 140,80,70 & \text { cry2 } \\ \text { CIBCM-105(A) } & \text { Carara } & \text { Soil } & \text { Ir } & 90,55,50 & \text { vips3 } \\ \text { CIBCM-107(A) } & \text { Carara } & \text { Soil } & \text { Ir } & 60,53,46 & \text { cry1, cry2, vips3 } \\ \text { CIBCM-151(A) } & \text { Gandoca-Manzanillo } & \text { Soil } & \text { Ir } & 96,80 & \text { vip3 } \\ \text { CIBCM-1 (A) } & \text { Braulio Carrillo } & \text { Soil } & \text { Ir } & 70,60,45 & \text { vip3 } \\ \text { CIBCM-251(A) } & \text { Palo Verde } & \text { Fresh leaves } & \text { Ov } & 110,95,85,41 & \text { cry2 } \\ \text { CIBCM-359(A) } & \text { Tortuguero } & \text { Soil } & \text { Ir } & 100,63,51 & \text { N amp } \\ \text { CIBCM-172(83) } & \text { Gandoca-Manzanillo } & \text { Soil } & \text { Ir, Ov } & 120,110,60 & \text { cry2, vip3 } \\ \text { CIBCM-172(123) } & \text { Gandoca-Manzanillo } & \text { Soil } & \text { Ir, Ov } & 65,53,41 & \text { cry2, vip3 } \\ \text { CIBCM-185(83) } & \text { Palo Verde } & \text { Soil } & \text { Ir, Ov } & 140,100,80 & \text { N amp } \\ \text { CIBCM-281(87) } & \text { Santa Rosa } & \text { Fresh leaves } & \text { Ir } & 70,85 & \text { cry2, cry8 }\end{array}$

$\mathrm{Bi}=$ bipyramidal, $\mathrm{Ir}=$ irregular, $\mathrm{Ov}=$ oval, $\mathrm{Cu}=$ cubic, $\mathrm{N}$ amp $=$ did not amplify with any of the primers used. 
